\title{
Selectively Reduced Expression of Synaptic Plasticity- Related Genes in Amyloid Precursor Protein + Presenilin-1 Transgenic Mice
}

\author{
Chad A. Dickey, ${ }^{1 \star}$ Jeanne F. Loring, ${ }^{2 \star}$ Julia Montgomery, ${ }^{2}$ Marcia N. Gordon, ${ }^{1}$ P. Scott Eastman, ${ }^{2}$ and Dave Morgan ${ }^{1}$ \\ ${ }^{1}$ Alzheimer's Disease Research Laboratory, Department of Pharmacology, University of South Florida, College of Medicine, Tampa, Florida 33612, and \\ 2Department of Life Sciences, Incyte Genomics, Palo Alto, California 94304
}

\begin{abstract}
A critical question in Alzheimer's disease (AD) research is the cause of memory loss that leads to dementia. The amyloid precursor protein + presenilin-1 (APP+PS1) transgenic mouse is a model for amyloid deposition, and like AD, the mice develop memory deficits as amyloid deposits accumulate. We profiled gene expression in these transgenic mice by microarray and quantitative RT-PCR (qRT-PCR). At the age when these animals developed cognitive dysfunction, they had reduced mRNA expression of several genes essential for long-term potentiation and memory formation (Arc, Zif268, NR2B, GluR1, Homer-1a, Nur77/TR3). These changes appeared to be related to amyloid deposition, because mRNA expression was unchanged in the regions that did not accumulate amyloid. Transgene expression was similar in both amyloid-containing and amyloid-free regions of the brain. Interestingly, these changes occurred without apparent changes in synaptic structure, because a number of presynaptic marker mRNAs (growth-associated protein-43, synapsin, synaptophysin, synaptopodin, synaptotagmin, syntaxin) remained stable. Additionally, a number of genes related to inflammation were elevated in transgenic mice, primarily in the regions containing amyloid. In AD cortical tissue, the same memory-associated genes were downregulated. However, all synaptic and neuronal transcripts were reduced, implying that the loss of neurons and synapses contributed to these changes. We conclude that reduced expression of selected genes associated with memory consolidation are linked to memory loss in both circumstances. This suggests that the memory loss in APP + PS1 transgenic mice may model the early memory dysfunction in AD before the degeneration of synapses and neurons.
\end{abstract}

Key words: Alzheimer’s; amyloid; immediate early genes; IEGs; memory; transgenic; real time PCR; cDNA microarray

\section{Introduction}

Memory loss is an early and progressive symptom of Alzheimer's disease (AD). During the period of cognitive decline, pathological hallmarks such as amyloid plaques and neurofibrillary tangles become evident (Selkoe, 2002). In the later stages of AD, there is a profound loss of synaptic markers, but early in the disease this loss is modest, and in some instances not discernable (Mukaetova-Ladinska et al., 2000; Tiraboschi et al., 2000; Masliah et al., 2001; Minger et al., 2001). A clue to understanding the basis of early memory loss in $\mathrm{AD}$ may come from transgenic mice that develop impaired memory function associated with amyloid deposition but never show the extensive loss of synapses or neurons typical of $\mathrm{AD}$.

The amyloid precursor protein + presenilin-1 $(\mathrm{APP}+\mathrm{PS} 1)$ mouse model of amyloid deposition develops a memory loss that is consistently observed by 15 months of age (Morgan et al., 2000; Arendash et al., 2001) and is correlated with the extent of amyloid deposition. Like $\mathrm{AD}$, these mice deposit amyloid primarily in the cerebral cortex and hippocampus, leaving the brainstem and cer-

\footnotetext{
Received Dec. 3, 2002; revised April 4, 2003; accepted April 7, 2003.

This work was supported by National Institute on Aging Grants AG15490 and AG18478. Dr. Tom Beach generously provided human tissue from the Brain Donation Program at Sun Health Research Institute in Sun City, AZ.

${ }^{*}$ C.A.D. and J.F.L. contributed equally to this work.

Correspondence should be addressed to Dave Morgan, University of South Florida, College of Medicine, Department of Pharmacology, Alzheimer's Disease Research Laboratory, 12901 Bruce B. Downs Boulevard, MDC 9, Tampa FL 33612. E-mail: dmorgan@hsc.usf.edu.

Copyright $\odot 2003$ Society for Neuroscience $\quad$ 0270-6474/03/235219-08\$15.00/0
}

ebellum essentially unaffected (Holcomb et al., 1998, 1999; Gordon et al., 2002). To assess changes that occur in the brain in conjunction with amyloid-associated memory loss, we used microarray analysis and quantitative RT-PCR (qRT-PCR) to survey the genes that were upregulated or downregulated in amyloidcontaining regions of APP+PS1 transgenic mouse brain. We found that the amyloid-containing regions of the transgenic mouse brain had high levels of expression of inflammationassociated genes, a characteristic that is also typical of $\mathrm{AD}$ brain. However, the most intriguing part of the gene expression profile was a selective decrease in transgenic mice of genes known to be important in long-term potentiation (LTP) and memory consolidation, restricted to amyloid-containing brain regions. Expression of genes involved in synaptic and neuronal structure was severely diminished in the human $\mathrm{AD}$ brain, but the transgenic animals did not show decreases in any of these genes. This suggests that the memory deficits in the early stages of human $\mathrm{AD}$ may be the result of dysfunctional changes that precede the frank loss of synapses.

\section{Materials and Methods}

Materials. Mice were bred in our facility and genotyped using previously described methods (Gordon et al., 2001). All mice were 17-18 months of age at time of death. Mice were deeply anesthetized with pentobarbital $(100 \mathrm{mg} / \mathrm{kg}$ ) and perfused transcardially with PBS. Brains were quickly removed, and amyloid-containing (cortex and hippocampus) and amyloid-free areas (cerebellum, striatum, and brainstem) were immedi- 
ately dissected and frozen on dry ice. For microarray analysis, cortex and hippocampus were pooled and dealt with as amyloid bearing samples, whereas cerebellum, striatum, and brainstem were combined and treated as amyloid-free tissues. For qRT-PCR, hippocampal RNA alone was isolated and regarded as amyloid-containing, whereas cerebellum alone was used for amyloid-free analysis. Transgenic and nontransgenic animals were killed in random order to minimize unintentional bias in handling of the samples. The working memory performance of the APP + PS1 mice used in these studies was significantly different from their nontransgenic littermates used as controls (Austin et al., 2003).

Fresh-frozen human cerebellar and medial temporal gyrus (Brodman's Area 21) specimens were obtained from the Brain Donation Program at Sun Health Research Institute (Sun City, AZ). Subjects with a clinical history of dementia were diagnosed as AD using neuropathologic consensus criteria, including those published by CERAD (Mirra et al., 1991) and the National Institute on Aging-Reagan Institute (1997). Control subjects did not have a clinical history of dementia and did not meet neuropathologic criteria for $\mathrm{AD}$ or other neurologic disorders. The average postmortem intervals were $2.6 \mathrm{hr}$ for $\mathrm{AD}$ and $2.3 \mathrm{hr}$ for control specimens ( six female, two male for $\mathrm{AD}$; six female, two male for agematched control). The average age for the $\mathrm{AD}$ specimens was 87 years, and the average age for the controls was 88 years.

Microarray analysis. Brain specimens from four 17- to 18-month-old $\mathrm{APP}+\mathrm{PS} 1$ transgenic mice or four nontransgenic littermates were grouped into two categories: amyloid-containing (cortex and hippocampus) and amyloid-free areas (cerebellum, striatum, and brainstem). mRNA was isolated from individual tissue samples, labeled with Cy3 or Cy5, and used for competitive hybridization to cDNA microarrays as described (Loring et al., 2001). Samples were analyzed pair wise (matched areas from transgenic and nontransgenic animals) on a total of 16 microarrays. The microarrays (eight Rat LifeArray 1 and eight Rat LifeArray 2; four each for the amyloid-containing region samples and the amyloid-free regions) used for this study were constructed from a collection of 15,981 rodent cDNAs representing 10,060 different genes (Incyte Genomics, Inc.). All of the sequences differentially expressed in the present study are $>90 \%$ identical in mouse and rat, and competitive hybridization of rat and mouse brain transcripts to these microarrays showed that $89 \%$ of the cDNA clones hybridized mouse and rat samples equally (data not shown). Microarrays constructed from the same library are currently available commercially from Agilent Technologies (Palo Alto, CA). Data collected from the microarray hybridizations were subjected to two low-frequency data correction algorithms to compensate for systematic variations in data quality as described previously (Yue et al., 2001).

To minimize the detection of false positive signals (type I statistical errors), the data were subjected to a two-stage criterion to identify genes of interest. The limit of detection of differential expression (LDDE) was calculated to be \pm 1 .4-fold by multiple quality control hybridizations as described previously (Yue et al., 2001). This LDDE indicates that in a single hybridization of an RNA sample against itself a 1.4-fold difference occurred with $p<0.01$. To further limit the number of false positive genes identified, we required that in three of the four individual hybridizations the differential expression value had to exceed 1.4 for a given gene to be analyzed further. For the second criterion, the statistical significance of the average differential expression value for any gene was calculated using Z-scores and a NORMSDIST function and was required to exceed a value of 1.4 (not simply 1.0 ) with $p<0.05$. In cases in which a given gene was represented by multiple sequences on the microarray, all data were combined for statistical analysis. Detailed analysis indicates that some sequences on microarrays are more variable in self-self hybridizations than others, leading to multiple false positives if one simply uses a differential expression value cutoff without sufficient replicates for statistical determinations. Moreover, because the variance estimates are sequence-specific, the use of Z-scores based on the variance estimate of all spots on the array is not always appropriate and should not be used as the only criterion in determining differentially expressed genes. One caveat against using these stringent criteria is an increased probability of type II statistical errors (false negatives). Still we believe that this ap- proach will identify those sequences that are most robustly and consistently modified.

For samples exhibiting significant differential expression in the amyloid-containing and amyloid-free brain areas of transgenic animals, a one-way ANOVA was performed. A planned post hoc comparison of means (least significant difference) was used to determine whether the expression was significantly different in the amyloid-containing versus the amyloid-free brain areas for individual genes. Each of the microarray clones that showed differential hybridization was unambiguously annotated by comparing its sequence (200-700 bp) with GenBank using the BLAST 2 algorithm.

$q R T-P C R$. Total RNA was prepared from dissected cerebellar and hippocampal tissue of eight APP + PS1 mice and eight nontransgenic littermates that were 17-18 months old. Memory deficits and amyloid burden were established in the transgenic mice by radial arm water maze testing and immunohistochemical methods, respectively (Austin et al., 2003). Human temporal cortex (medial temporal gyrus; Brodmans area 21) and cerebellar tissue samples from eight $\mathrm{AD}$ patients and eight age-matched controls were pulverized by mortar and pestle on dry ice, and 10-30 mg of this powdered tissue was used to extract RNA. The homogenates from rotor-stator emulsification (Tissuemizer) of all tissues used were applied to RNeasy mini-spin columns (Qiagen) with on-column DNase treatment followed by elution with RNase-free water, according to the manufacturer's specifications. All total RNA samples were then reverse transcribed with a 1:1 mixture of oligo dT ( $25 \mathrm{ng} / \mu \mathrm{l}$; Invitrogen $)$ and random hexamers $(2.5 \mathrm{ng} / \mu \mathrm{l}$; Invitrogen $)$ to provide ample cDNA synthesis from both 18 S rRNA (Schmittgen and Zakrajsek, 2000) and poly-adenylated mRNA. The final reverse-transcription reaction included template (described below), $1 \mathrm{~m}$ betaine (Sigma-Aldrich), providing more heat lability to nucleic acid and protein thermo-stabilization, $1 \times$ cDNA firststrand synthesis buffer (Invitrogen), $7 \mathrm{~mm} \mathrm{MgCl}, 1 \mathrm{~mm}$ dNTPs (each A, G, C, T Invitrogen), $40 \mathrm{U}$ of RNaseOut (Invitrogen), 3 mm DTT (Invitrogen), and $25 \mathrm{U}$ of recombinant Superscript II reverse transcriptase (Invitrogen). The reaction was brought to $20 \mu \mathrm{l}$ with water and then incubated for $15 \mathrm{~min}$ at $25^{\circ} \mathrm{C}$, followed by $30 \mathrm{~min}$ at $42^{\circ} \mathrm{C}$ and then $30 \mathrm{~min}$ at $60^{\circ} \mathrm{C}$. The reaction was then heated at $95^{\circ} \mathrm{C}$ to denature the enzymes and stop the reaction. A standard curve was established within the RT reaction by adding total RNA (template) from an intra-experimental mouse or human RNA pool covering three logs $(50,20,10,5,2,1,0.5$, and 0.2 ng) to separate wells. Two mass quantities (10 and $2 \mathrm{ng}$ ) of total RNA from all samples being investigated were added to individual wells within the RT reaction for comparison with the standard curve. The RNA standard curve verifies the linearity of the RT-PCR reaction and controls for slight inefficiencies in the transcription and amplification steps of the procedure (below).

Primer pairs for qRT-PCR were generated to amplify $\sim 100 \mathrm{bp}$ fragments of the gene of interest using the web-based applications Primer3 and the Oligo Toolkit. These oligos were tailored according to the species being analyzed. Primers were initially optimized using a PCR reaction followed by agarose gel analysis. If ethidium bromide staining revealed a single band, the primer concentrations were optimized by comparing at least three concentrations of each primer and noting which combination was most efficient at generating a PCR product (using SYBR green detection; see below), without producing signal in control wells lacking template. Experimental wells containing cDNA $25 \mu \mathrm{l}$ PCR reactions were run in triplicate and consisted of a master mix containing $12.5 \mu \mathrm{l}$ of $2 \times$ SYBR Green Master Mix (Applied Biosystems), 0.25-4.5 $\mu$ l of forward and reverse primers in varied combinations, and either $2 \mu \mathrm{l}$ of cDNA from an RT reaction or $2 \mu \mathrm{l}$ of water, to control for nonspecific amplification attributable to self-priming or contamination. The remainder of the $25 \mu \mathrm{l}$ volume was achieved by adding water; 96-well plates were mixed by pipetting and then centrifuged. Two-step PCR was run on the MJ Research Opticon (Boston, MA) as follows: 1 cycle of $95^{\circ} \mathrm{C}$ for $15 \mathrm{~min}$ followed by 40 cycles of $95^{\circ} \mathrm{C}$ for $15 \mathrm{sec}$ and $60-65^{\circ} \mathrm{C}$ for $1 \mathrm{~min}$ (primer annealing temperature is decided according to the Operon website calculations). This was followed by melt curve analysis beginning at $55^{\circ} \mathrm{C}$ and increasing by $1^{\circ} \mathrm{C}$ to $100^{\circ} \mathrm{C}$ every $10 \mathrm{sec}$, with fluorescence measured at every interval. None of the primer pairs demonstrated more than one 
Table 1. Expression of neuronal genes in transgenic mice compared with nontransgenic mice (array and qRT-PCR data)

\begin{tabular}{|c|c|c|c|c|c|}
\hline \multirow[b]{2}{*}{ Marker mRNA } & \multirow[b]{2}{*}{ Protein function } & \multicolumn{2}{|c|}{$\begin{array}{l}\text { Array data } \\
\text { Percentage of nontransgenic mean } \pm \text { SEM } \\
\text { (z-score in parentheses) }\end{array}$} & \multicolumn{2}{|c|}{$\begin{array}{l}\text { qRT-PCR data } \\
\text { Percentage of nontransgenic mean } \pm \text { SEM }\end{array}$} \\
\hline & & Amyloid-containing area & Amyloid-free area & Amyloid-containing area & Amyloid-free area \\
\hline $\operatorname{Arc}$ & LTP-associated structural & $64 \pm 3^{*}(2.8)$ & $108 \pm 6(0.4)$ & $48 \pm 10^{*}$ & $97 \pm 5$ \\
\hline Calsyntenin & Postsynaptic $\mathrm{Ca}^{2+}$ signaling & $64 \pm 3^{*}(2.8)$ & $79 \pm 5(1.33)$ & $99 \pm 9$ & ND \\
\hline Gap43 & Neuritic growth, plasticity & $115 \pm 7(0.75)$ & $87 \pm 7(0.75)$ & $104 \pm 10$ & $94 \pm 4$ \\
\hline GAPDH & Energy metabolism & $91 \pm 4(0.49)$ & $97 \pm 1(0.15)$ & $82 \pm 7$ & ND \\
\hline GluR1 & Postsynaptic receptor & $102 \pm 2(0.1)$ & $105 \pm 3(0.25)$ & $70 \pm 10^{*}$ & $95 \pm 6$ \\
\hline Homer-1a & LTP-associated, regulatory & ND & ND & $60 \pm 7^{*}$ & $95 \pm 9$ \\
\hline $\mathrm{Na}$, KATPase $\alpha$ III & Neuronal ion gradient, transmission & $66 \pm 4^{*}(2.6)$ & $77 \pm 3(1.5)$ & $57 \pm 4^{*}$ & $99 \pm 5$ \\
\hline$N A B 2$ & LTP-related, regulatory & ND & ND & $115 \pm 7$ & ND \\
\hline Neurofilament M & Neuronal structural & $103 \pm 1(0.15)$ & $104 \pm 1(0.20)$ & $82 \pm 7$ & ND \\
\hline$N R 2 B$ & Receptor implicated in memory consolidation & ND & ND & $82 \pm 5^{*}$ & $99 \pm 5$ \\
\hline Nur-77 & LTP-associated, regulatory & $61 \pm 4^{*}(3.2)$ & $77 \pm 1(1.5)$ & ND & ND \\
\hline Synapsin & Presynaptic vesicle-associated & $71 \pm 8^{*}(2.0)$ & $92 \pm 2(0.4)$ & $103 \pm 7$ & $82 \pm 18$ \\
\hline Synaptophysin & Presynaptic vesicle-associated & $126 \pm 8(1.3)$ & $91 \pm 4(0.5)$ & $101 \pm 5$ & $98 \pm 5$ \\
\hline Synaptopodin & LTP-associated structural & ND & ND & $91 \pm 5$ & ND \\
\hline Synaptotagmin 5 & Presynaptic vesicle-associated & $98 \pm 4(0.1)$ & $106 \pm 2(0.3)$ & $106 \pm 19$ & ND \\
\hline Syntaxin & Presynaptic vesicle-associated & ND & ND & $94 \pm 7$ & ND \\
\hline Zif268 & LTP-associated, regulatory & $60 \pm 5^{*}(3.3)$ & $88 \pm 8(0.68)$ & $45 \pm 8^{*}$ & $82 \pm 3^{*}$ \\
\hline
\end{tabular}

*Significantly different from nontransgenic mice at $p<0.05$. GAPDH, Glyceraldehyde-3-phosphate dehydrogenase; ND, not determined. (Please contact authors for details regarding genes.)

peak of fluorescence as derived from the Opticon software, indicating a single gene product without primer-dimer formation.

The target gene primers demonstrated similar amplification efficiencies as compared with $18 \mathrm{~S}$ ribosomal RNA, allowing for quantitation of fold-change using $18 \mathrm{~S}$ signals to normalize the results for the quantity of starting RNA. The slope of the regression line for the standard curve determined efficiency, which varied by $<5 \%$ for all amplicons. Samples were run in triplicate, with both the 10 and 2 ng RT reactions represented for each. Standard curve samples were included on all plates to avoid errors caused by minor plate-to-plate variations in amplification efficiency. The standard curve was calculated by plotting the threshold cycle [ $(\mathrm{Ct})$ the point at which relative fluorescence exceeds a fixed value above background against the log nanogram quantity of RNA added to the RT reactions]. A linear regression was performed, and the slope-relating $\mathrm{Ct}$ to $\log$ RNA was calculated. The average $\mathrm{Ct}$ for each sample was then used to determine the corresponding log nanogram of standard RNA using the slope of the standard curve. These logarithmic values were then converted to a mass quantity of standard RNA according to Ct. These mass values for the genes of interest were then divided by the $18 \mathrm{~S}$ values of the same sample to determine fold-change in expression relative to the standard RNA pool. For each region these fold-change values for samples in the experimental (transgenic or $\mathrm{AD}$ ) and control (nontransgenic or agematched nondiseased) groups were analyzed for significance using oneway ANOVA. The differential expression value between regions was similarly compared using one-way ANOVA.

\section{Results}

The mice used for analysis were 17- to 18-month-old APP+PS1 transgenic mice that demonstrated impaired working memory performance compared with nontransgenic littermates (Morgan et al., 2000; Austin et al., 2003). Different mice were used for microarray and qRT-PCR studies. We first used a competitive hybridization approach to compare transcripts from transgenic mouse brain with matched nontransgenic tissues on cDNA microarrays. Instead of assigning an arbitrary cutoff value to detect changes in regulation, the microarray analysis was based on multiple arrays with independent samples and statistical comparisons to determine those genes that were differentially expressed (see Materials and Methods). Using the rigorous criteria for the microarray analysis set forth above (see Materials and Methods), only five genes demonstrated significantly decreased expression in the amyloid-containing areas (hippocampus plus cortex for the array studies) of the transgenic animals (Table 1). This group of genes included three genes that are essential for normal memory function (Arc, Zif268, Nur77/TR3) and two associated with neuronal/synaptic activity $\left(\mathrm{Na}^{+}, \mathrm{K}^{+}\right.$ATPase $\alpha \mathrm{III}$, calsyntenin $)$. Except for Zif268 (see below), these reductions were restricted to amyloid-containing brain regions and did not occur in regions from the same mice that were amyloid free (cerebellum, striatum, brainstem in the array studies) (Table 1), although transgene expression was high in these regions (see below).

Using qRT-PCR, we saw a similar pattern of specific amyloidassociated downregulation for most of the genes in this group (Table 1). Because of the $50 \%$ reduction in the memoryassociated genes Zif268 and Arc found with the microarray, we expanded the qRT-PCR analysis to include other genes related to synaptic function and memory processes (Fig. 1). This analysis showed that the transcript for the ionotropic glutamate receptor 1 (GluR1/AMPA1) was downregulated by $30 \%$, and the NMDA receptor subunit $2 B$ (NR2B) RNA, known to be critical for cognitive processes (Tang et al., 1999), was decreased by $18 \%$ in amyloid-containing tissue (hippocampus alone for qRT-PCR studies). Expression of Homer-1a, which is a member of the Homer family of metabotropic glutamate receptor binding proteins (Brakeman et al., 1997), was reduced by $40 \%$. Not only were these genes significantly downregulated in comparison with nontransgenic mice, they were also decreased significantly compared with the expression in amyloid-free tissue (cerebellum only for qRT-PCR studies) for the same animals (Fig. 1, bracket above bars). Only one of the synaptic plasticity-related genes was significantly downregulated in the amyloid-free region: Zif268 expression measured by qRT-PCR was $18 \%$ lower in the cerebellum, which was still significantly less reduced than in the hippocampus (Fig. 1).

Not all of the synaptic plasticity genes that we examined were changed in the transgenic mice. Expression of synaptopodin (Mundel et al., 1997), which is argued to be involved in synaptic plasticity, was not changed, nor was growth-associated protein (GAP-43), also involved in synaptic plasticity and sprouting (Routtenberg et al., 2000), suggesting that not all synaptic plasticity genes were modified in the transgenic animals. Other synaptic-neuronal markers were also expressed at normal levels in the transgenic animals, including synaptophysin, neurofilament- $M$, synapsin-1, and synaptotagmin $V$. 
The stability of these essentially presynaptic markers was also observed in the results from the microarray study (Table 1).

The microarray analyses revealed an upregulation of a group of genes associated with inflammation and the acute phase response (Table 2). We quantified the upregulation of three of these genes by qRT-PCR [glial fibrillary acidic protein (GFAP), Apolipoprotein E (ApoE), and vimentin]. Expression of GFAP, an astrocyte-specific intermediate filament, was increased by 6.3-fold in the APP+PS1 mice compared with nontransgenic littermates (Table 3). This reflects the astrocyte proliferation known to occur in the APP + PS1 animals (Holcomb et al., 1998) and is consistent with earlier immunoassay results measuring this protein (Gordon et al., 2002). Additionally, another non-neuronal intermediate filament, $v i$ mentin, was upregulated by more than twofold, and $A p o E$, another acute phase protein, was upregulated to a lesser extent. These data are consistent with earlier reports describing reproducible glial activation and acute phase reactivity in the APP+PS1 mice (Holcomb et al., 1998; Matsuoka et al., 2001; Gordon et al., 2002). Most of these genes were unaffected in the areas of the transgenic brain that were relatively free of plaques. However, a few of the genes were also upregulated in non-plaque-bearing regions ( $\mathrm{Ta}$ ble 3). Two of these genes were highly expressed because they contained a sequence that was homologous to the sequence of the APP transgene. The APP transcripts on the microarray and the array sequences corresponding to the prion protein $5^{\prime}$ untranslated region [part of the transgene promoter construct (Hsiao et al., 1996)] were elevated to the same extent in both the amyloid-containing and amyloid-free regions. Sequences on the microarray that encoded other regions of the prion gene were unaffected in transgenic animals (data not shown). Notably, except for the transgenes and two others, the elevation in the amyloid-containing regions was significantly greater than in the amyloid-free regions of the transgenic brain (Table 3, asterisks). Coupled with the absence of upregulation in amyloid-free regions for most of the genes in Table 2, it seems likely that the modest upregulation of several inflammationrelated genes in these amyloid-free regions reflects a lower level of generalized inflammation in these areas.

We considered it critical to compare the expression of the synaptic marker genes in the mouse model with specimens from AD patients. A previous microarray analysis (Loring et al., 2001) indicated that many markers of synapses were decreased in the amyloid-containing areas of $\mathrm{AD}$ brain. We extended this analysis by qRT-PCR measurements of a group of synaptic markers in the medial temporal gyrus of the cerebral cortex and cerebellum of eight $\mathrm{AD}$ patients and eight cognitively normal age-matched controls. As shown in Figure 2, all of the postsynaptic plasticityassociated transcripts that we analyzed were significantly underexpressed by $>50 \%$ in the amyloid-containing cortical region, whereas the amyloid-free cerebellar tissue lacked any significant change in expression of the same genes, consistent with the relative sparing of the cerebellum in AD. In this manner the pattern of changes in transgenic mice and AD cases was similar. However, in contrast to the observations that we made for the mouse, in samples of AD MTG all of the other synaptic markers (synaptophysin, synapsin, synaptopodin, synaptotagmin, GAP-43) were also reduced, as was neurofilament $M$. Similar to the transgenic mouse, GFAP was elevated in the amyloid-containing region of the AD brain. Also similar to the mouse, there were no significant changes in the amyloid-free human cerebellum, coupling amyloid to the apparent loss of mRNA in the AD samples. These data are consistent with the considerable evidence showing neurodegeneration and synaptic loss in amyloid-containing regions of late stage $\mathrm{AD}$. The results also highlight the similarities and differences between the severe loss of most cognitive function in $\mathrm{AD}$ and the relatively selective memory loss in amyloid-depositing transgenic mice that do not undergo neurodegeneration (Matsuoka et al., 2001).

\section{Discussion}

The results of our microarray and qRT-PCR study show that the expression of several postsynaptic genes known to be integral for the establishment of LTP and long-term memory was selectively downregulated in the amyloid-containing regions of memorydeficient APP + PS1 mice. The amyloid-free regions of these transgenic mice do not exhibit the same downregulation. Additionally, several presynaptic genes that are often used as synaptic or neuronal markers are unaltered in these animals, similar to 


\section{Table 2. Genes that are upregulated in amyloid-containing areas of transgenic mice brains compared with the same areas of nontransgenic mice brains (microarray data)}

\begin{tabular}{|c|c|c|}
\hline Function and location & Gene name & $\begin{array}{l}\text { Percentage of } \\
\text { nontransgenic } \\
\text { mean } \pm \text { SEM } \\
\text { (z-score in parentheses }\end{array}$ \\
\hline \multicolumn{3}{|l|}{ Inflammation } \\
\hline \multirow{16}{*}{$\begin{array}{l}\text { Secreted/cell } \\
\text { surface }\end{array}$} & $\alpha 1$ type III collagen & $162 \pm 7^{*}(3.3)$ \\
\hline & $\alpha$-fibrinogen Fga & $368 \pm 46^{*}(13.6)$ \\
\hline & $\beta$-2-microglobulin & $203 \pm 9^{*}(5.4)$ \\
\hline & $\beta-5$ integrin & $190 \pm 11^{*}(4.7)$ \\
\hline & $\beta$-galactoside-binding lectin & $177 \pm 14^{*}(4.1)$ \\
\hline & $C d 63$ & $193 \pm 16^{*}(4.9)$ \\
\hline & Complement component (1q $\alpha$ chain & $289 \pm 27^{*}(9.6)$ \\
\hline & Complement component $\mathrm{C} 1 q \beta$ chain & $200 \pm 16^{*}(5.2)$ \\
\hline & Complement component C4 & $297 \pm 22^{*}(10.1)$ \\
\hline & Histidine-rich glycoprotein & $172 \pm 13^{*}(3.8)$ \\
\hline & Ig heavy chain VDJh2 region & $160 \pm 10^{*}(3.2)$ \\
\hline & Lysozyme & $183 \pm 8^{*}(4.4)$ \\
\hline & MHC class I & $166 \pm 6^{*}(3.5)$ \\
\hline & MHC class IA1(f) $\alpha$ chain RT1.A1(f) & $182 \pm 8^{*}(4.3)$ \\
\hline & Transferrin & $178 \pm 10^{*}(4.1)$ \\
\hline & Tyrosine kinase binding protein & $254 \pm 6^{*}(7.9)$ \\
\hline \multirow[t]{2}{*}{ Cytoskeletal } & Glial fibrillary acidic protein & $483 \pm 64^{*}(19.4)$ \\
\hline & Vimentin & $181 \pm 14^{*}(4.3)$ \\
\hline \multirow[t]{3}{*}{ Lysosomal } & Cathepsin D & $253 \pm 32^{*}(7.9)$ \\
\hline & Cathepsin S & $248 \pm 21^{*}(7.6)$ \\
\hline & Cathepsin Y & $187 \pm 22^{*}(4.6)$ \\
\hline \multicolumn{3}{|l|}{ Acute-phase reaction } \\
\hline \multirow[t]{4}{*}{ Lipid binding } & Acyl-CoA binding protein & $166 \pm 6^{*}(3.5)$ \\
\hline & Apolipoprotein D & $159 \pm 10^{*}(3.2)$ \\
\hline & Apolipoprotein E & $160 \pm 4^{*}(3.2)$ \\
\hline & Niemann pick type 22 & $180 \pm 12^{*}(4.2)$ \\
\hline \multirow[t]{5}{*}{ Intracellular } & $\alpha$-D-mannosidase & $162 \pm 7^{*}(3.3)$ \\
\hline & Cystathionine beta-synthase & $377 \pm 22^{*}(14.1)$ \\
\hline & Kelch-like 1 & $189 \pm 15^{*}(4.7)$ \\
\hline & $\begin{array}{l}\text { Mitochondrial } 6 \text {-trimethyllysine } \\
\text { 2-oxoalutarate dioxvaenase }\end{array}$ & $175 \pm 21^{*}(4.0)$ \\
\hline & $\begin{array}{l}\text { 2-oxoglutarate dioxygenase } \\
\text { Serine protease inhibitor }\end{array}$ & $161 \pm 21^{*}(3.3)$ \\
\hline \multirow{2}{*}{$\begin{array}{l}\text { Secreted/cell } \\
\text { surface }\end{array}$} & SPI-2 serine protease inhibitor & $176 \pm 14^{*}(4.0)$ \\
\hline & Thyroid hormone receptor $\alpha$ & $618 \pm 73^{*}(26.1)$ \\
\hline
\end{tabular}

*All entries are significantly different from amyloid-containing regions of nontransgenic mice at $p<0.05$. (Please contact authors for details regarding genes.)

recent microarray findings in APP transgenic mice at an age preceding amyloid deposition (Stein and Johnson, 2002). These findings indicate that the failure of APP + PS1 mice to consolidate information for future recall may be precipitated by the amyloiddependent downregulation of genes known to be critical for cognitive function.

Late-phase LTP is thought to correspond to some forms of long-term memory consolidation because of the requirement for de novo protein synthesis for both processes (Morris, 1998). In APP transgenic mice, the formation of LTP is impaired in some but not all studies (Chapman et al., 1999; Larson et al., 1999; Fitzjohn et al., 2001). Recently it was found that oligomeric forms of the A $\beta$ peptide were particularly effective at impairing LTP when injected into the hippocampus in vivo (Walsh et al., 2002). Of particular relevance are previous observations that the plasticity-related genes that we examined are essential for latephase LTP and long-term memory formation (Bolshakov et al., 1997; Ma et al., 1999). Antisense oligonucleotides against Arc mRNA intracranially injected into rats eliminated both latephase LTP and long-term memory formation without affecting short-term forms of both processes (Guzowski et al., 2000). Mice with a targeted inactivation of Zif268 also lack the ability to express long-term synaptic and behavioral plasticity, although short-term forms of plasticity remain intact (Jones et al., 2001). It has been reported that overexpression of the NR2B subunit leads to improved memory function (Tang et al., 1999), whereas intracranial injection of antisense oligonucleotides directed against NR2B mRNA inhibits LTP and cognitive function (Clayton et al., 2002). Additionally, there is a large amount of evidence suggesting an aggregation of AMPA receptors (GluRs) and metabotropic glutamate receptors (mGluRs) with NMDA receptors via proteins such as Homer and PSD95, further linking LTP with memory storage (Xiao et al., 1998; Ango et al., 2000). Homer-1a is elevated after synaptic activation and plays a role in targeting mGluRs to synapses (Ango et al., 2000). Therefore all of these genes are known to play a role in cognitive ability, and their selective downregulation in a mouse model of amyloidassociated memory deficits establishes them as possible candidates for pharmacotherapeutic approaches to $\mathrm{AD}$.

Although many of the genes known to influence memory were diminished in the APP + PS1 mice, there were several in our study that did not show downregulated expression. GAP-43, one of the unchanged genes, has been shown to improve cognitive function when overexpressed in transgenic mice (Routtenberg et al., 2000). Synaptopodin, another protein linked to plasticity (Mundel et al., 1997; Deller et al., 2000; Yamazaki et al., 2001), is also stable in the amyloid-containing regions of the APP + PS1 mouse brain. These data imply that amyloid is selective in downregulating only certain memory-associated genes, which are mostly postsynaptic. Several mechanisms might account for these changes. One possibility is direct interaction of $A \beta$ with one or more signal transduction pathways. Alternatively, the regulation could be via an indirect pathway involving the acute phase response (e.g., cytokine effects secondary to amyloid-induced microglia activation). The first idea is supported by the fact that several of the downregulated genes are immediate early genes that can be induced by activating the extracellular signal-related kinase (ERK) signaling cascade (Davis et al., 2000; Mazzucchelli et al., 2002). A $\beta$ itself appears capable of modifying ERK signaling (Dineley et al., 2001), potentially interfering with expression of these genes. Alternatively, because the induction of these IEGs is dependent on synaptic activity, a generalized decrease in neuronal activity caused by $\mathrm{A} \beta$ might also explain the reductions in expression. There is also evidence supporting the indirect mode of regulation, because the glial reactions leading to the activation of inflammatory mediators correspond temporally to the period when memory loss is occurring (Gordon et al., 2002). Dissociating between these mechanisms and identifying the specific components involved will also benefit development of rational pharmacotherapies for $\mathrm{AD}$.

We observed that many of the memory-associated genes were similarly deficient in the amyloid-containing regions of the human AD brain, confirming earlier reports from our group and others (Ginsberg et al., 2000; Loring et al., 2001; Bi and Sze, 2002). However, interpretation of this observation is complicated by the fact that multiple neuronal and synaptic marker genes were also underexpressed in the $\mathrm{AD}$ cortex that we examined. Our samples were from relatively late-stage $\mathrm{AD}$, however, when amyloid deposition and neuronal dysfunction are extensive, and several reports indicate that widespread loss of synapses appears to follow, not precede, loss of memory function. In a detailed study of synaptic markers during the course of $\mathrm{AD}$, it was reported that loss of synaptic markers occurred only in Braak stages 5 and 6, late in the disease when the pathology is most widespread (Mukaetova- 
Table 3. Genes that are upregulated in both amyloid-containing brain regions and amyloid-free brain regions of transgenic mice (array and qRT-PCR data)

\begin{tabular}{|c|c|c|c|c|}
\hline \multirow[b]{2}{*}{ Marker RNA } & \multicolumn{2}{|c|}{$\begin{array}{l}\text { Array data } \\
\text { Percentage of nontransgenic mean } \pm \text { SEM }\end{array}$} & \multicolumn{2}{|c|}{$\begin{array}{l}\text { qRT-PCR data } \\
\text { Percentage of nontransgenic mean } \pm \text { SEM }\end{array}$} \\
\hline & Amyloid-containing area & Amyloid-free area & Amyloid-containing area & Amyloid-free area \\
\hline \multicolumn{5}{|l|}{ Transgene } \\
\hline$A P P$ & $192 \pm 7(4.8)$ & $209 \pm 7(5.7)$ & ND & ND \\
\hline Prion protein (UTR) & $223 \pm 15(6.4)$ & $242 \pm 14(7.3)$ & ND & ND \\
\hline \multicolumn{5}{|l|}{ Inflammation } \\
\hline Apolipoprotein E & $160 \pm 4(3.2)$ & $171 \pm 10(3.8)$ & $156 \pm 16$ & ND \\
\hline$\alpha$-1 type Ill collagen & $162 \pm 7(3.3)$ & $167 \pm 12(3.6)$ & ND & ND \\
\hline Complement component $\mathrm{C} 1 q \alpha$ chain & $289 \pm 27^{*}(9.7)$ & $182 \pm 18^{*}(4.3)$ & ND & ND \\
\hline Complement component $\mathrm{C} 4$ & $297 \pm 22 *(10.1)$ & $154 \pm 8^{*}(2.9)$ & ND & ND \\
\hline Cystathionine $\beta$-synthase & $377 \pm 22 *(14.1)$ & $194 \pm 16^{*}(4.9)$ & ND & ND \\
\hline GFAP & $483 \pm 64^{*}(19.4)$ & $182 \pm 13 *(4.3)$ & $629 \pm 115$ & ND \\
\hline Thyroid hormone receptor $\alpha$ & $618 \pm 73 *(26.1)$ & $234 \pm 24^{*}(6.9)$ & ND & ND \\
\hline Tyrosine kinase binding protein & $254 \pm 6^{*}(7.9)$ & $161 \pm 7^{*}(3.3)$ & ND & ND \\
\hline
\end{tabular}

*Data in bold are significantly more highly expressed in amyloid-containing regions than amyloid-free regions of transgenic mice. ND, Not determined.

Ladinska et al., 2000). Another study (Tiraboschi et al., 2000) failed to detect changes in the synaptic markers synaptophysin or choline acetyl transferase in mild AD [Mini-mental state examination $(\mathrm{MMSE})=20$ ], and a third report found that mildly demented individuals (clinical dementia rating $0.5-1$ ) had no change in synaptotagmin or GAP-43, although a slight reduction in synaptophysin was found that worsened as the disease progressed (Masliah et al., 2001). A study by Minger et al. (2001) found that only in AD cases that were severe (MMSE <4) was there a significant reduction in choline acetyltransferase, synaptophysin, syntaxin, or SNAP-25. None of these studies examined the synaptic plasticity markers that we observed to be decreased in the transgenic mice. In light of this evidence and our observations, we propose that the APP + PS1 mouse that (1) develops both forebrain-specific amyloid deposits and memory deficits, (2) suffers acute phase reactions in the brain, and (3) has decreased memory-associated gene expression without the loss of synaptic integrity markers is likely to be an appropriate model for anterograde amnesias found in early stage $\mathrm{AD}$.

Transgenic models for human disease have become a critical tool in the progression of therapeutic strategies to clinical trials. It is crucial, therefore, to validate the models for specific characteristics of the human disease. This report describes further characterization of a transgenic mouse model that constitutively expresses both the human APP and PS1 genes containing mutations that are known to accelerate amyloid deposition and dementia in $\mathrm{AD}$ cases. The transcripts of several postsynaptic genes that are thought to be essential for the retention of memory and maintenance of LTP are specifically downregulated in the cognitive areas of APP + PS1 mouse brain without the loss of expression of genes involved in synaptic function. When these genes were analyzed in late-stage human $\mathrm{AD}$ temporal
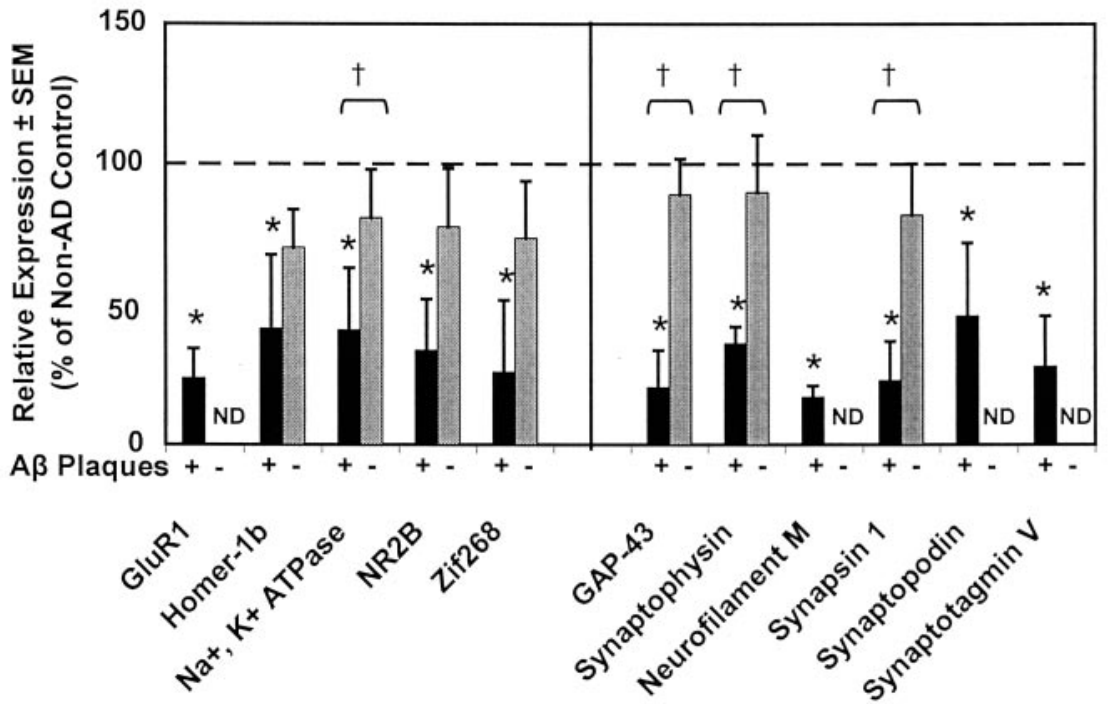

Figure 2. Gene expression profile of Alzheimer disease tissue in amyloid-containing and amyloid-free brain regions by qRTPCR. The differential expression (Alzheimer relative to age-matched normals) is presented for genes that are primarily postsynaptic (left half of figure) and those that are primarily presynaptic (right half of figure). The relative expression in the amyloidcontaining region (temporal cortex; area 21; black bars) and amyloid-free region (cerebellum; gray bars) is shown when both regions were analyzed. These regions are also designated in the line to the right of $A \beta$ Plaques with a + symbol beneath the bar indicating amyloid containing region or a - symbol beneath the bar indicating an amyloid-free region. After $q R T-P C R$, each gene transcript level for each sample is first normalized to 18S RNA measurements from the same RT. For each region, relative expression was determined by dividing each Alzheimer sample value by the average of the age-matched normal values. The relative expression values for the amyloid-containing and amyloid-free regions could also be compared statistically to determine whether the reduction in expression was different in the two structures. The values represented in this figure are the mean \pm SEM. We did not determine cerebellum measurements for several genes as indicated by ND in place of the bar on the figure. Asterisks indicate significant differences between Alzheimer and age-matched normals $(p<0.05)$. $\uparrow$ symbol above the bracket indicates diseaseassociated downregulation to a greater extent $(p<0.05)$ in the amyloid-containing than the amyloid-free regions.

cortex, we found that the same memory-associated genes were downregulated, but unlike the mouse, all markers for synaptic integrity and neuronal stability were also underexpressed. Along with the activation of glial cells and induction of acute-phase reactants, the fact that the APP+PS1 mice deposit amyloid in the forebrain, develop anterograde amnesia, and have altered expression of these memory-associated genes specifically in the cognitive domains of the brain suggests that some form of amyloid is facilitating the memory loss in these animals.

These data also contribute to the growing pool of evidence 
that specific genes such as Arc, Zif268, NR2B, and Homer-1a are critical to normal memory function and that their dysregulation may underlie the early phase of memory loss that occurs in $\mathrm{AD}$. Therefore it will be of great interest to evaluate methods to upregulate these genes as potential therapeutic targets for use in early stage $\mathrm{AD}$ and possibly other disorders involving memory deficiency.

\section{References}

Ango F, Pin JP, Tu JC, Xiao B, Worley PF, Bockaert J, Fagni L (2000) Dendritic and axonal targeting of type 5 metabotropic glutamate receptor is regulated by homerl proteins and neuronal excitation. J Neurosci 20:8710-8716.

Arendash GW, King DL, Gordon MN, Morgan D, Hatcher JM, Hope CE, Diamond DM (2001) Progressive, age-related behavioral impairments in transgenic mice carrying both mutant amyloid precursor protein and presenilin-1 transgenes. Brain Res 891:42-53.

Austin LA, Arendash GW, Gordon G, Diamond DM, DiCarlo G, Dickey C, Ugen KE, Morgan D (2003) Short-term A-beta vaccinations do not improve cognitive performance in cognitively-impaired APP + PS1 mice. Behav Neurosci, in press.

Bi H, Sze CI (2002) N-methyl-D-aspartate receptor subunit NR2A and NR2B messenger RNA levels are altered in the hippocampus and entorhinal cortex in Alzheimer's disease. J Neurol Sci 200:11-18.

Bolshakov VY, Golan H, Kandel ER, Siegelbaum SA (1997) Recruitment of new sites of synaptic transmission during the cAMP-dependent late phase of LTP at CA3-CA1 synapses in the hippocampus. Neuron 19:635-651.

Brakeman PR, Lanahan AA, O’Brien R, Roche K, Barnes CA, Huganir RL, Worley PF (1997) Homer: a protein that selectively binds metabotropic glutamate receptors. Nature 386:284-288.

Chapman PF, White GL, Jones MW, Cooper-Blacketer D, Marshall VJ, Irizarry M, Younkin L, Good MA, Bliss TV, Hyman BT, Younkin SG, Hsiao KK (1999) Impaired synaptic plasticity and learning in aged amyloid precursor protein transgenic mice. Nat Neurosci 2:271-276.

Clayton DA, Mesches MH, Alvarez E, Bickford PC, Browning MD (2002) A hippocampal NR2B deficit can mimic age-related changes in long-term potentiation and spatial learning in the Fischer 344 rat. J Neurosci 22:3628-3637.

Davis S, Vanhoutte P, Pages C, Caboche J, Laroche S (2000) The MAPK/ ERK cascade targets both Elk-1 and cAMP response element-binding protein to control long-term potentiation-dependent gene expression in the dentate gyrus in vivo. J Neurosci 20:4563-4572.

Deller T, Merten T, Roth SU, Mundel P, Frotscher M (2000) Actinassociated protein synaptopodin in the rat hippocampal formation: localization in the spine neck and close association with the spine apparatus of principal neurons. J Comp Neurol 418:164-181.

Dineley KT, Westerman M, Bui D, Bell K, Ashe KH, Sweatt JD (2001) $\beta$-Amyloid activates the mitogen-activated protein kinase cascade via hippocampal $\alpha 7$ nicotinic acetylcholine receptors: in vitro and in vivo mechanisms related to Alzheimer's disease. J Neurosci 21:4125-4133.

Fitzjohn SM, Morton RA, Kuenzi F, Rosahl TW, Shearman M, Lewis H, Smith D, Reynolds DS, Davies CH, Collingridge GL, Seabrook GR (2001) Age-related impairment of synaptic transmission but normal long-term potentiation in transgenic mice that overexpress the human APP695SWE mutant form of amyloid precursor protein. J Neurosci 21:4691-4698.

Ginsberg SD, Hemby SE, Lee VM, Eberwine JH, Trojanowski JQ (2000) Expression profile of transcripts in Alzheimer's disease tangle-bearing CA1 neurons. Ann Neurol 48:77-87.

Gordon MN, King DL, Diamond DM, Jantzen PT, Boyett KV, Hope CE, Hatcher JM, DiCarlo G, Gottschall WP, Morgan D, Arendash GW (2001) Correlation between cognitive deficits and Abeta deposits in transgenic APP+PS1 mice. Neurobiol Aging 22:377-385.

Gordon MN, Holcomb LA, Jantzen PT, DiCarlo G, Wilcock D, Boyett KW, Connor K, Melachrino J, O'Callaghan JP, Morgan D (2002) Time course of the development of Alzheimer-like pathology in the doubly transgenic PS1+APP mouse. Exp Neurol 173:183-195.

Guzowski JF, Lyford GL, Stevenson GD, Houston FP, McGaugh JL, Worley PF, Barnes CA (2000) Inhibition of activity-dependent arc protein expression in the rat hippocampus impairs the maintenance of long-term potentiation and the consolidation of long-term memory. J Neurosci 20:3993-4001.

Holcomb L, Gordon MN, McGowan E, Yu X, Benkovic S, Jantzen P, Wright K, Saad I, Mueller R, Morgan D, Sanders S, Zehr C, O'Campo K, Hardy J, Prada CM, Eckman C, Younkin S, Hsiao K, Duff K (1998) Accelerated Alzheimer-type phenotype in transgenic mice carrying both mutant amyloid precursor protein and presenilin 1 transgenes. Nat Med 4:97-100.

Holcomb LA, Gordon MN, Jantzen P, Hsiao K, Duff K, Morgan D (1999) Behavioral changes in transgenic mice expressing both amyloid precursor protein and presenilin-1 mutations: lack of association with amyloid deposits. Behav Genet 29:177-185.

Hsiao K, Chapman P, Nilsen S, Eckman C, Harigaya Y, Younkin S, Yang F, Cole G (1996) Correlative memory deficits, Abeta elevation, and amyloid plaques in transgenic mice. Science 274:99-102.

Jones MW, Errington ML, French PJ, Fine A, Bliss TV, Garel S, Charnay P, Bozon B, Laroche S, Davis S (2001) A requirement for the immediate early gene Zif268 in the expression of late LTP and long-term memories. Nat Neurosci 4:289-296.

Larson J, Lynch G, Games D, Seubert P (1999) Alterations in synaptic transmission and long-term potentiation in hippocampal slices from young and aged PDAPP mice. Brain Res 840:23-35.

Loring JF, Wen X, Lee JM, Seilhamer J, Somogyi R (2001) A gene expression profile of Alzheimer's disease. DNA Cell Biol 20:683-695.

Ma L, Zablow L, Kandel ER, Siegelbaum SA (1999) Cyclic AMP induces functional presynaptic boutons in hippocampal CA3-CA1 neuronal cultures. Nat Neurosci 2:24-30.

Masliah E, Mallory M, Alford M, DeTeresa R, Hansen LA, McKeel Jr DW, Morris JC (2001) Altered expression of synaptic proteins occurs early during progression of Alzheimer's disease. Neurology 56:127-129.

Matsuoka Y, Picciano M, Malester B, LaFrancois J, Zehr C, Daeschner JM, Olschowka JA, Fonseca MI, O'Banion MK, Tenner AJ, Lemere CA, Duff K (2001) Inflammatory responses to amyloidosis in a transgenic mouse model of Alzheimer's disease. Am J Pathol 158:1345-1354.

Mazzucchelli C, Vantaggiato C, Ciamei A, Fasano S, Pakhotin P, Krezel W, Welzl H, Wolfer DP, Pages G, Valverde O, Marowsky A, Porrazzo A, Orban PC, Maldonado R, Ehrengruber MU, Cestari V, Lipp HP, Chapman PF, Pouyssegur J, Brambilla R (2002) Knockout of ERK1 MAP kinase enhances synaptic plasticity in the striatum and facilitates striatalmediated learning and memory. Neuron 34:807-820.

Minger SL, Honer WG, Esiri MM, McDonald B, Keene J, Nicoll JA, Carter J, Hope T, Francis PT (2001) Synaptic pathology in prefrontal cortex is present only with severe dementia in Alzheimer disease. J Neuropathol Exp Neurol 60:929-936.

Mirra SS, Heyman A, McKeel D, Sumi SM, Crain BJ, Brownlee LM, Vogel FS, Hughes JP, van Belle G, Berg L (1991) The consortium to establish a registry for Alzheimer's disease (CERAD). Part II. Standardization of the neuropathologic assessment of Alzheimer's disease. Neurology 41:479-486.

Morgan D, Diamond DM, Gottschall PE, Ugen KE, Dickey C, Hardy J, Duff K, Jantzen P, DiCarlo G, Wilcock D, Connor K, Hatcher J, Hope C, Gordon M, Arendash GW (2000) A beta peptide vaccination prevents memory loss in an animal model of Alzheimer's disease. Nature 408:982-985.

Morris RG (1998) Synaptic plasticity. Down with novelty. Nature 394:834-835.

Mukaetova-Ladinska EB, Garcia-Siera F, Hurt J, Gertz HJ, Xuereb JH, Hills R, Brayne C, Huppert FA, Paykel ES, McGee M, Jakes R, Honer WG, Harrington CR, Wischik CM (2000) Staging of cytoskeletal and beta-amyloid changes in human isocortex reveals biphasic synaptic protein response during progression of Alzheimer's disease. Am J Pathol 157:623-636.

Mundel P, Heid HW, Mundel TM, Kruger M, Reiser J, Kriz W (1997) Synaptopodin: an actin-associated protein in telencephalic dendrites and renal podocytes. J Cell Biol 139:193-204.

National Institute on Aging-Reagan Institute (1997) Consensus recommendations for the postmortem diagnosis of Alzheimer's disease. The National Institute on Aging, and Reagan Institute Working Group on Diagnostic Criteria for the Neuropathological Assessment of Alzheimer's Disease. Neurobiol Aging 18:S1-S2.

Routtenberg A, Cantallops I, Zaffuto S, Serrano P, Namgung U (2000) Enhanced learning after genetic overexpression of a brain growth protein. Proc Natl Acad Sci USA 97:7657-7662. 
Schmittgen TD, Zakrajsek BA (2000) Effect of experimental treatment on housekeeping gene expression: validation by real-time, quantitative RTPCR. J Biochem Biophys Methods 46:69-81.

Stein TD, Johnson JA (2002) Lack of neurodegeneration in transgenic mice overexpressing mutant amyloid precursor protein is associated with increased levels of transthyretin and the activation of cell survival pathways. J Neurosci 22:7380-7388.

Tang YP, Shimizu E, Dube GR, Rampon C, Kerchner GA, Zhuo M, Liu G, Tsien JZ (1999) Genetic enhancement of learning and memory in mice. Nature 401:63-69.

Tiraboschi P, Hansen LA, Alford M, Masliah E, Thal LJ, Corey-Bloom J (2000) The decline in synapses and cholinergic activity is asynchronous in Alzheimer's disease. Neurology 55:1278-1283.

Walsh DM, Klyubin I, Fadeeva JV, Cullen WK, Anwyl R, Wolfe MS, Rowan MJ,
Selkoe DJ (2002) Naturally secreted oligomers of amyloid beta protein potently inhibit hippocampal long-term potentiation in vivo. Nature 416:535-539.

Xiao B, Tu JC, Petralia RS, Yuan JP, Doan A, Breder CD, Ruggiero A, Lanahan AA, Wenthold RJ, Worley PF (1998) Homer regulates the association of group 1 metabotropic glutamate receptors with multivalent complexes of homer-related, synaptic proteins. Neuron 21:707-716.

Yamazaki M, Matsuo R, Fukazawa Y, Ozawa F, Inokuchi K (2001) Regulated expression of an actin-associated protein, synaptopodin, during long-term potentiation. J Neurochem 79:192-199.

Yue H, Eastman PS, Wang BB, Minor J, Doctolero MH, Nuttall RL, Stack R, Becker JW, Montgomery JR, Vainer M, Johnston R (2001) An evaluation of the performance of cDNA microarrays for detecting changes in global mRNA expression. Nucleic Acids Res 29:E41-1. 